\title{
Increased intramyocellular lipids but unaltered in vivo mitochondrial oxidative phosphorylation in skeletal muscle of adipose triglyceride lipase-deficient mice.
}

Citation for published version (APA):

Nunes, P. M., van de Weijer, T., Veltien, A., Arnts, H., Hesselink, M. K. C., Glatz, J. F., Schrauwen, P., Tack, C., \& Heerschap, A. (2012). Increased intramyocellular lipids but unaltered in vivo mitochondrial oxidative phosphorylation in skeletal muscle of adipose triglyceride lipase-deficient mice. American Journal of Physiology : Endocrinology and Metabolism, 303(1), E71-E81.

https://doi.org/10.1152/ajpendo.00597.2011

Document status and date:

Published: 01/07/2012

DOI:

10.1152/ajpendo.00597.2011

Document Version:

Publisher's PDF, also known as Version of record

Document license:

Taverne

Please check the document version of this publication:

- A submitted manuscript is the version of the article upon submission and before peer-review. There can be important differences between the submitted version and the official published version of record.

People interested in the research are advised to contact the author for the final version of the publication, or visit the DOI to the publisher's website.

- The final author version and the galley proof are versions of the publication after peer review.

- The final published version features the final layout of the paper including the volume, issue and page numbers.

Link to publication

\footnotetext{
General rights rights.

- You may freely distribute the URL identifying the publication in the public portal. please follow below link for the End User Agreement:

www.umlib.nl/taverne-license

Take down policy

If you believe that this document breaches copyright please contact us at:

repository@maastrichtuniversity.nl

providing details and we will investigate your claim.
}

Copyright and moral rights for the publications made accessible in the public portal are retained by the authors and/or other copyright owners and it is a condition of accessing publications that users recognise and abide by the legal requirements associated with these

- Users may download and print one copy of any publication from the public portal for the purpose of private study or research.

- You may not further distribute the material or use it for any profit-making activity or commercial gain

If the publication is distributed under the terms of Article $25 \mathrm{fa}$ of the Dutch Copyright Act, indicated by the "Taverne" license above, 


\title{
Increased intramyocellular lipids but unaltered in vivo mitochondrial oxidative phosphorylation in skeletal muscle of adipose triglyceride lipase-deficient mice
}

\author{
P. M. Nunes, ${ }^{1}$ T. van de Weijer, ${ }^{2}$ A. Veltien, ${ }^{1}$ H. Arnts,${ }^{3}$ M. K. C. Hesselink, ${ }^{4}$ J. F. C. Glatz, ${ }^{5}$ \\ P. Schrauwen, ${ }^{2}$ C. J. Tack, ${ }^{6}$ and A. Heerschap ${ }^{1}$ \\ ${ }^{1}$ Department of Radiology, Radboud University Nijmegen Medical Centre, Nijmegen, The Netherlands; ${ }^{2}$ Department of \\ Human Biology, NUTRIM, School of Nutrition Toxicology and Metabolism, Maastricht University Medical Centre, \\ Maastricht, The Netherlands; ${ }^{3}$ Central Animal Laboratory, Radboud University Nijmegen Medical Centre, Nijmegen, \\ The Netherlands; ${ }^{4}$ Department of Human Movement Sciences, Maastricht University Medical Centre, Maastricht, \\ The Netherlands; ${ }^{5}$ Department of Molecular Genetics, Maastricht University, Maastricht, The Netherlands; and ${ }^{6}$ Department of \\ General Internal Medicine, Radboud University Nijmegen Medical Centre, Nijmegen, The Netherlands
}

Submitted 23 November 2011; accepted in final form 6 April 2012

\begin{abstract}
Nunes PM, van de Weijer T, Veltien A, Arnts H, Hesselink MK, Glatz JF, Schrauwen P, Tack CJ, Heerschap A. Increased intramyocellular lipids but unaltered in vivo mitochondrial oxidative phosphorylation in skeletal muscle of adipose triglyceride lipase-deficient mice. Am J Physiol Endocrinol Metab 303: E71-E81, 2012. First published April 10, 2012; doi:10.1152/ajpendo.00597.2011._Adipose triglyceride lipase (ATGL) is a lipolytic enzyme that is highly specific for triglyceride hydrolysis. The ATGL-knockout mouse $\left(\mathrm{ATGL}^{-1-}\right)$ accumulates lipid droplets in various tissues, including skeletal muscle, and has poor maximal running velocity and endurance capacity. In this study, we tested whether abnormal lipid accumulation in skeletal muscle impairs mitochondrial oxidative phosphorylation, and hence, explains the poor muscle performance of $\mathrm{ATGL}^{-1-}$ mice. In vivo ${ }^{1} \mathrm{H}$ magnetic resonance spectroscopy of the tibialis anterior of $\mathrm{ATGL}^{-1-}$ mice revealed that its intramyocellular lipid pool is approximately sixfold higher than in WT controls $(P=0.0007)$. In skeletal muscle of ATGL $^{-1-}$ mice, glycogen content was decreased by $30 \%(P<$ 0.05). In vivo ${ }^{31} \mathrm{P}$ magnetic resonance spectra of resting muscles showed that WT and $\mathrm{ATGL}^{-1-}$ mice have a similar energy status: $[\mathrm{PCr}],\left[\mathrm{P}_{\mathrm{i}}\right], \mathrm{PCr} / \mathrm{ATP}$ ratio, $\mathrm{PCr} / \mathrm{P}_{\mathrm{i}}$ ratio, and intracellular $\mathrm{pH}$. Electrostimulated muscles from WT and $\mathrm{ATGL}^{-1-}$ mice showed the same $\mathrm{PCr}$ depletion and $\mathrm{pH}$ reduction. Moreover, the monoexponential fitting of the $\mathrm{PCr}$ recovery curve yielded similar $\mathrm{PCr}$ recovery times $\left(\tau \mathrm{PCr} ; 54.1 \pm 6.1 \mathrm{~s}\right.$ for the $\mathrm{ATGL}^{-1-}$ and $58.1 \pm 5.8 \mathrm{~s}$ for the WT $)$, which means that overall muscular mitochondrial oxidative capacity was comparable between the genotypes. Despite similar in vivo mitochondrial oxidative capacities, the electrostimulated muscles from $\mathrm{ATGL}^{-1-}$ mice displayed significantly lower force production and increased muscle relaxation time than the WT. These findings suggest that mechanisms other than mitochondrial dysfunction cause the impaired muscle performance of $\mathrm{ATGL}^{-1-}$ mice.
\end{abstract}

${ }^{31} \mathrm{P}$ magnetic resonance spectroscopy; exercise

ADIPOSE TRIGLYCERIDE LIPASE (ATGL), also known as desnutrin, is a ubiquitous lipolytic enzyme expressed mainly in hepatocytes, testes, adipocytes, and myocytes $(29,33,38,51,54,58)$. This lipase is highly specific for triglycerides (TG) and catalyzes the first step of its hydrolysis (58). Whole body ATGLknockout mice $\left(\mathrm{ATGL}^{-1-}\right.$ ) are mildly obese and accumulate lipids in various tissues such as skeletal muscle and heart and ultimately develop lethal cardiomyopathy (16). The ATGL ${ }^{-1-}$ mice have reduced plasma free fatty acids (FFA), significantly

Address for reprint requests and other correspondence: P. Nunes, Dept. of Radiology, Radboud University Nijmegen Medical Centre, Postbus 9101 Geert Grooteplein 10, 6500 HB Nijmegen, Netherlands (e-mail: P.Nunes@ rad.umcn.nl). improved insulin sensitivity, and glucose tolerance, showing evidence of a reliance on oxidation of glucose instead of fatty acid (FA) to produce energy $(16,19,30,41)$.

FAs are the major energy substrates for muscle under submaximal exercise. Thus, diminished FA availability is one of the explanations for the exercise intolerance and poor endurance capacity of the ATGL $^{-1-}$ mice $(19,47)$. Reduced exercise performance could also be explained by the cardiac dysfunction that the $\mathrm{ATGL}^{-1-}$ mice present at older age (19). However, young $\mathrm{ATGL}^{-1-}$ mice without cardiac lipid accumulation and adult $\mathrm{ATGL}^{-1-}$ mice with a normal cardiac ATGL expression still present abnormal exercise performance $(19,47)$. These studies show that, even with a normal cardiac function, $\mathrm{ATGL}^{-1-}$ mice remain exercise intolerant.

While whole body ATGL ablation causes tissue-specific adaptations (30), the most pronounced modulation of biological processes by ATGL occurs in cardiac muscle. In this tissue, genetic ablation of ATGL results in a downregulation of the transcripts associated with oxidative pathways, namely genes involved in FA uptake and mitochondrial $\beta$-oxidation, as well as in glycolysis and the tricarboxylic acid cycle (42). Furthermore, a recent study demonstrated that mitochondrial substrate oxidation and respiration are severely disrupted in cardiac muscle of $\mathrm{ATGL}^{-1-}$ mice due to peroxisome proliferatoractivated receptor signaling (17).

Although modulation of skeletal muscle metabolism by ATGL is not as prominent as in cardiac muscle, downregulation of genes involved in ATP biosynthesis has been reported for $\mathrm{ATGL}^{-1-}$ skeletal muscle (42). Moreover, the accumulation of intramyocellular lipids (IMCL) in skeletal muscle might be associated with mitochondrial dysfunction, as in obese or type 2 diabetic patients $(25,39,40)$, through a mechanism not fully understood but probably involving the accumulation of active lipid intermediates along with IMCL deposition, deficits in mitochondrial $\beta$-oxidation, and increased formation of reactive oxygen species $(44,46,48)$. Whether the IMCL accumulation affects skeletal muscle mitochondrial function in $\mathrm{ATGL}^{-1-}$ mice is unknown.

Taken together, these data suggest that the compromised exercise performance of $\mathrm{ATGL}^{-1-}$ mice is not explained solely by the inability to generate FFA for muscle oxidation but could be associated with reduced mitochondrial oxidative capacity. Therefore, we hypothesized that $\mathrm{ATGL}^{-1-}$ mice have impaired muscular mitochondrial function, which contributes to their poor exercise tolerance. 
To test this hypothesis, we evaluated in vivo and noninvasively the extent of IMCL accumulation in the skeletal muscle of $\mathrm{ATGL}^{-1-}$ mice using ${ }^{1} \mathrm{H}$ magnetic resonance spectroscopy (MRS). To assess mitochondrial oxidative capacity of $\mathrm{ATGL}^{-1-}$ mice in vivo, gated dynamic ${ }^{31} \mathrm{P}-\mathrm{MRS}$ of electrostimulated muscles was recorded. These parameters were correlated with force production and postcontraction relaxation time of $\mathrm{ATGL}^{-1-}$ muscle.

\section{MATERIALS AND METHODS}

Animals. All of the experimental procedures were approved by the Radboud University Nijmegen Medical Centre Animal Ethics Committee, Nijmegen, The Netherlands.

$\mathrm{ATGL}^{-1-}$ mice, obtained by targeted homologous recombination, as described before (16), were a kind gift from R. Zechner, Institute of Molecular Biosciences, University of Graz, Austria. ATGL ${ }^{-1-}$ and wild-type (WT) littermate mice were generated by breeding heterozygous mice for the deleted allele. Male ATGL ${ }^{-\prime-}(8 \pm 1 \mathrm{wk})$ and WT control mice $(10 \pm 2 \mathrm{wk})$ used in this study were housed under a 12:12-h light-dark cycle with controlled temperature $\left(22-24^{\circ} \mathrm{C}\right)$. Animals had permanent ad libitum access to mouse standard chow and water.

MRS studies. All in vivo MR studies were performed on a 7 Tesla horizontal magnet interfaced with a clinical console (Clinscan; Bruker Biospin, Ettlingen, Germany). During surgical procedures and MR measurements, mice were anesthetized with 1-2\% isoflurane (Pharmachemie, Haarlem, The Netherlands) in a gas mixture of 50:50\% $\mathrm{O}_{2}-\mathrm{N}_{2} \mathrm{O}$ delivered through a face mask. Body temperature was maintained at $37^{\circ} \mathrm{C}$ using heating pads and monitored rectally with a fluoroptic thermometer (Luxtron 712; Luxtron, Santa Clara, CA). Mouse breathing was monitored in the scanner by using a pressure sensor to record thorax movement (SA Instruments).

Intramyocellular lipid levels were measured in vivo in the tibialis anteriors (TA) of seven ATGL ${ }^{-1-}$ and nine WT mice by single voxel ${ }^{1} \mathrm{H}$-MRS, as described previously (15), with minor adaptations. Briefly, mice were anesthetized and their left legs positioned under a four-element array ${ }^{1} \mathrm{H}$ surface coil to align the TA muscle fibers with the magnetic field, which provides optimal spectral separation between the resonances of extra and IMCLs. Anatomic reference images were taken using a spin-echo pulse sequence [repetition time (TR) of 2,500 ms and echo time (TE) of $30 \mathrm{~ms}$ ] for careful positioning of a $3.1 \times 1 \times 1 \mathrm{~mm}^{3}$ voxel within the TA. Automatic first- and second-order shimming was performed using the FASTMAP method in the same voxel. The ${ }^{1} \mathrm{H}-\mathrm{MR}$ spectra were acquired using a PRESS sequence with an additional six outer volume suppression bands and the following parameters: TR/TE $=1,500 / 16 \mathrm{~ms}$ and 1,024 averages. Two ${ }^{1} \mathrm{H}$ spectra were acquired, one without and the other with water suppression, which was achieved using the VAPOR method.

Skeletal muscle mitochondrial oxidative capacity was assessed in vivo in nine $\mathrm{ATGL}^{-1-}$ and $10 \mathrm{WT}$ mice using ${ }^{31} \mathrm{P}$-MRS. Contraction of the calf muscle complex, i.e., gastrocnemius (GAST) and soleus (SOL) muscles, was achieved by electrostimulation of the sciatic nerve, as described previously (24). After anesthesia, a minor incision was made in the mouse hip and the sciatic nerve exposed. To avoid contraction of the dorsal flexors, the peroneal nerve was severed (43). An electrode (tensile flex UT3607TF) was tunneled through the upper leg and connected to the sciatic nerve by stitching the electrode to the surrounding tissue, leaving the nerve in its natural position. A second electrode was fed through the skin near the Achilles tendon, functioning as ground reference for the stimulation pulses. The mouse was positioned in the setup in its prone position and the hindleg was placed on top of the MR-compatible force transducer by fixing the foot in a close fitting cradle and the knee into a cavity in a Perspex plate at an $\sim 90^{\circ}$ angle. Optimal stimulation current was determined by varying the current $(1.25-2.5 \mathrm{~mA})$ to elicit isometric tetanic contractions, with a pulse train of 250-ms duration and stimulus frequency of $150 \mathrm{~Hz}$, yielding the maximal force. Stimulation of the calf muscle complex occurred every $3 \mathrm{~s}$ over $1 \mathrm{~min}$ (muscle duty cycle of $8 \%$ ). The stimulation frequency of $150 \mathrm{~Hz}$ was chosen to generate fully fused isometric tetani at maximum force, as determined by frequency-force relationship in SOL and GAST of WT mice $(22,23)$.

A dual coil setup consisting of a ${ }^{31} \mathrm{P}$ solenoid coil $(121.5 \mathrm{MHz})$ was used for unlocalized ${ }^{31} \mathrm{P}-\mathrm{MRS}$ and a ${ }^{1} \mathrm{H}$ surface coil (300.2 MHz) used for reference MR imaging and localized shimming of the hindleg. A user interface was designed to control the stimulation, measure force transduction, and synchronize the measurements to the timing of the pulse sequences using LabView.

Initially, one ${ }^{31} \mathrm{P}-\mathrm{MR}$ spectrum was acquired $(\mathrm{TR}=10 \mathrm{~s}$, no. of points $=2,048$; spectral width of $5 \mathrm{kHz}, 64$ averages) with the mouse leg at rest. Subsequently, eight time series of ${ }^{31} \mathrm{P}-\mathrm{MR}$ spectra were acquired before ( $\mathrm{TR}=10 \mathrm{~s}, 10 \mathrm{scans})$, during ( $\mathrm{TR}=9 \mathrm{~s}, 6$ scans), and after $(\mathrm{TR}=10 \mathrm{~s}, 30 \mathrm{scans})$ the muscle contractions. Isometric tetanic contractions of the muscle $(250 \mathrm{~ms}, 150 \mathrm{~Hz})$ occurred every 3 s over a period of $1 \mathrm{~min}$, summing 20 contractions per cycle.

After the electrostimulation protocol, samples of contracted and resting contralateral hindlimb were freeze-clamped and immediately stored in liquid nitrogen. Additionally, blood was withdrawn from the hepatic vein and centrifuged and plasma recovered from centrifugation at $1,000 \mathrm{~g}$ for $10 \mathrm{~min}$. Tissue and plasma samples were stored at $-80^{\circ} \mathrm{C}$ until further analysis.

Data processing of in vivo studies. All ${ }^{1} \mathrm{H}$ - and ${ }^{31} \mathrm{P}-\mathrm{MR}$ spectra were fitted in the time domain by using AMARES (53) in the jMRUI software package (36). The IMCL level in the TA muscle was calculated from the lipid methylene peak area $(1.33 \mathrm{ppm})$ and expressed relatively to the total creatine $(\mathrm{tCr})$ methyl peak area $(3.02$ ppm).

The eight time series of $46{ }^{31} \mathrm{P}-\mathrm{MR}$ spectra were added retrospectively, and peak areas of inorganic phosphate $\left(\mathrm{P}_{\mathrm{i}}\right)$, phosphocreatine (PCr), and $\gamma^{-}, \alpha-$, and $\beta$-ATP signals were fitted by Gaussian line shapes. Absolute concentrations of the phosphorus metabolites were calculated assuming that at rest the mouse muscles have $7.8 \mathrm{mM}$ of ATP (20). Intracellular $\mathrm{pH}$ was calculated from the chemical shift difference between $\mathrm{P}_{\mathrm{i}}$ and $\mathrm{PCr}$ resonances (50). The recovery of $\mathrm{PCr}$ after the contractions was fitted with a monoexponential function (GraphPad 5.03; GraphPad Software, La Jolla, CA). The PCr recovery time $(\tau \mathrm{PCr})$ value is the in vivo measurement of skeletal muscle mitochondrial oxidative capacity.

Signals derived from the force transducer were digitized to a sampling frequency of $50 \mathrm{kHz}$ and analyzed with Matlab (Mathworks, Natick, MA), where each contraction was filtered and peak force and half relaxation time [HRT; the time in which the force falls from one-half to one-quarter of the maximal value of each contraction (11, 12)] were determined. Force production was normalized to the crosssectional area (CSA) of the muscle, determined from the hindlimb axial images obtained prior to the electrostimulation protocol. CSA was determined for the entire hindlimb muscle region by delineating it from the slices where all animals had similar tibial bone area (1.4 \pm $0.1 \mathrm{~mm}^{2}$ ), using Image J software (NIH Image version 1.44; http:// rsbweb.nih.gov/ij/).

Skeletal muscle electron microscopy. Ultrastructural morphology was examined using transmission electron microscopy. Muscle tissue sections from extensor digitorum longus (EDL) and the SOL were

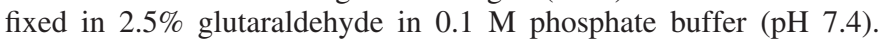
Postfixation was performed in $1 \%$ osmium tetroxide in $0.1 \mathrm{M}$ cacodylate buffer ( $\mathrm{pH} 7.4$ ) supplemented with $1.5 \%$ potassium ferrocyanide. The samples were then dehydrated and embedded in epon. Ultrathin sections were examined using a Philips CM100 electron microscope. Lipid droplet (LD) diameter and content were determined in EDL and SOL using Image $J$ software.

Fiber typing of TA. The fiber type composition of TA was determined by immunohistochemical analyses in serial cross-cryosections of the muscle that were mounted carefully in uncoated glass slides. 
The relative proportion of type I and type II fibers was determined with specific antibody against myosin heavy chain type I (A4.840, diluted 1:25 in PBS; Developmental Studies Hybridoma Bank) combined with Alexa 555-conjugated secondary antibody.

Slides were analyzed using a fluorescence microscope (Model E800; Nikon Instruments Europe, Badhoevedorp, The Netherlands) coupled with a progressive scan color charge-coupled device camera with a (Basler A113 C) color filter (Bayer). Epifluorescence signal was recorded using a fluorescein isothiocyanate excitation filter (465$495 \mathrm{~nm}$ ) for muscle fiber type and a 4',6-diamino-2-phenylindole UV excitation filter $(340-380 \mathrm{~nm})$ for laminin.

Digital images were captured with a magnification of 120 from at least six different fields of view per muscle section and processed with Lucia version 4.81 software.

Intraperitoneal glucose tolerance test. One week before the MRS measurements, mice were fasted for $6 \mathrm{~h}$ and injected intraperitoneally with a bolus of glucose $(1.5 \mathrm{~g} / \mathrm{kg})$. Blood glucose levels were monitored before and 15, 30, 60, 90, and 120 min after injection with an Accu-Chek performa glucometer (Roche, Manheim, Germany).

Resting and contraction induced-metabolite depletion. Absolute tissue concentrations of high-energy phosphate compounds were determined in resting muscle from $\mathrm{ATGL}^{-1-}$ and WT mice, as described before (57). Briefly, muscles were rapidly excised and freezeclamped, followed by extraction with $1.3 \mathrm{M}$ perchloric acid and neutralization with $1 \mathrm{M}$ potassium bicarbonate. Thereafter, tissue contents of PCr, free $\mathrm{Cr}$, and ATP were determined by high-performance liquid chromatography.

To determine the contraction cost in muscle glycogen content, freeze-clamped samples of contracted and contralateral resting hindlimbs were first powdered under a liquid nitrogen atmosphere. Muscle tissue was then digested with two volumes of potassium hydroxide $30 \%(\mathrm{wt} / \mathrm{vol})$ at $70^{\circ} \mathrm{C}$ for $30 \mathrm{~min}$. The precipitation of glycogen was achieved by adding $1 \mathrm{ml}$ of $6 \%$ (wt/vol) sodium sulphate and $6 \mathrm{ml}$ of $99.9 \%$ ethanol to the digested tissue. Samples were kept overnight at $4^{\circ} \mathrm{C}$. The samples were then centrifuged, the supernatant was discarded, and the pellet was resuspended in $50 \mathrm{mM}$ sodium acetate, $\mathrm{pH}$ 4.5. Sixteen units of amyloglucosidase from Aspergillus niger (Sigma-Aldrich, Steinheim, Germany) were added to hydrolyze the glycogen into glucose monomers. Samples were incubated overnight at $55^{\circ} \mathrm{C}$, and $\mathrm{pH}$ was then readjusted to 7 . Glucose monomers were quantified using an assay kit (Invitrogen, Breda, The Netherlands). Glycogen levels were expressed in glucosyl units per gram of wet weight.

Plasma levels of glucose, lactate, and FFA were determined from mice that underwent the electrostimulation protocol, using enzymatic colorimetric assays [Invitrogen; Eton Bioscience, Durham, NC; and Wako HR (2), Wako Diagnostics, Neuss, Germany]. Triglyceride levels were determined using a clinical Cardiocheck analyzer (Polymer Technology Systems, Indianapolis, IN).

Statistical analysis. Statistical analyses were performed using GraphPad prism 5.03 (GraphPad Software). Differences between genotypes were evaluated by applying unpaired Student's $t$-test or two-way ANOVA with a Bonferroni post hoc test as appropriate. Statistical significance was set at $P<0.05$.

\section{RESULTS}

Relevant characteristics of $\mathrm{ATGL}^{-1-}$ and WT mice are presented in Table 1 . The average body weight of ATGL ${ }^{-1-}$ mice was higher than their WT littermates $(P<0.001)$. Plasma glucose levels were similar between the genotypes at fed state and after $6 \mathrm{~h}$ of fasting. The glucose-tolerant phenotype of the ATGL $^{-/-}$mice was confirmed by a glucose challenge showing lower plasma glucose levels at $15(11.7 \pm 1.0 \mathrm{mM}$ for ATGL $^{-1-}$ vs. $14.4 \pm 0.9 \mathrm{mM}$ for WT mice) and $60 \mathrm{~min}(7.7 \pm$ $0.5 \mathrm{mM}$ for $\mathrm{ATGL}^{-1-}$ vs. $10.6 \pm 0.5 \mathrm{mM}$ for WT mice)
Table 1. Characteristics of $A T G L^{-/-}(n=14)$ and WT mice $(n=16)$

\begin{tabular}{lcr}
\hline \hline & ATGL $^{-1-}$ & WT \\
\hline Age, wk & $8 \pm 1$ & $10 \pm 2$ \\
Body weight, g & $25.8 \pm 0.3 * * *$ & $23.0 \pm 0.4$ \\
Fed glycemia, mM & $8.2 \pm 0.6$ & $8.9 \pm 0.5$ \\
6-h-Fasted glycemia, mM & $7.4 \pm 0.5$ & $7.7 \pm 0.5$ \\
IPGTT AUC, mM/min & $1,067 \pm 54^{* *}$ & $1,277 \pm 56$ \\
\hline
\end{tabular}

Values are presented as means $\pm \mathrm{SD}$; statistical differences indicated with Student's $t$-test for $P<0.05$. ATGL, adipose triglyceride lipase; WT, wild type; IPGTT, intraperitoneal glucose tolerance test; AUC, area under the curve. $* *$ and ***Significantly different from WT $P<0.01$ and $P<0.001$.

postbolus injection. ATGL ${ }^{-1-}$ mice also have lower intraperitoneal glucose tolerance test area under the curve $(P<0.01)$.

IMCL content and fiber type composition. To evaluate lipid accumulation in ATGL ${ }^{-1-}$ muscles, the EDL and the SOL muscles were analyzed for IMCL content by electron microscopy (Fig. 1A). LDs were larger and more numerous in the SOL muscle (comprised mainly of red oxidative fibers) of $\mathrm{ATGL}^{-1-}$ mice compared with WT mice. This observation, although less pronounced, was also valid for the EDL muscles, which have a more glycolytic phenotype (Fig. $1 B$ ). Interestingly, it was observed that in $\mathrm{ATGL}^{-1-}$ muscles, neighboring fibers have profound differences in LD content and size; fibers with higher mitochondrial content and thicker Z-lines (most likely representing the more oxidative fibers in the EDL) had abundant and fairly large LDs, in contrast to fibers with a low mitochondrial content and thinner Z-lines (a characteristic of glycolytic fibers). In both muscles from the $\mathrm{ATGL}^{-/-}$mice, signs of autophagy, as well as crystal-like structures in the LDs, were detectable. Despite the aberrant lipid deposition in skeletal muscle of ATGL ${ }^{-1-}$ mice, no abnormal features were observed in the mitochondrial morphology or in the structure of the contractile filaments.

The IMCL pool was also assessed in vivo in TA muscle of $\mathrm{ATGL}^{-1-}$ and WT mice by ${ }^{1} \mathrm{H}-\mathrm{MRS}$. This muscle was chosen due to its natural alignment with the magnetic field, a prerequisite to resolve the resonances of extra- and intramyocellular lipids $(3,4)$. To quantify these two lipid pools with localized ${ }^{1} \mathrm{H}-\mathrm{MRS}$, a small voxel $(3.1 \mu \mathrm{l})$ was positioned inside of the TA muscle. In the spectra of all mice, ATGL ${ }^{-1-}$ and $\mathrm{WT},{ }^{1} \mathrm{H}$ resonances of only IMCL were visible in the methylene and methyl spectral region. Signals of extramyocellular lipids were detected when larger voxels were applied (6.2 $\mu \mathrm{l}$; see Fig. $2 A)$. In ${ }^{1} \mathrm{H}-\mathrm{MR}$ spectra of ATGL ${ }^{-1-}$ mice, the height of the IMCL peak representing the methylene protons $(1.33 \mathrm{ppm})$ was substantially increased compared with that of the WT mice (Fig. 2A). IMCL content in TA was normalized for $\mathrm{tCr}$ (Fig. 2B), and this ratio was approximately six times higher in TA of $\mathrm{ATGL}^{-1-}$ mice than in the TA of WT mice $(5.6 \pm 2.9$ vs. $1.1 \pm$ $0.9, P=0.0007)$.

Changes in muscle fiber type composition can occur in response to skeletal muscle lipid surplus (49). However, this was not observed in the TA muscle of $\mathrm{ATGL}^{-1-}$ mice. Irrespective of genotypes, the TA maintained its major composition of type II (fast-twitch) fibers (Fig. 3A). TA muscle from $\mathrm{ATGL}^{-1-}$ mice was composed of $81.1 \pm 4.8$ vs. $18.9 \pm 4.8 \%$ type II and type I fibers compared with $79.6 \pm 5.8$ vs. $20.4 \pm$ $5.8 \%$ type II and type I fibers in WT (Fig. 3B). 
A

ATGL

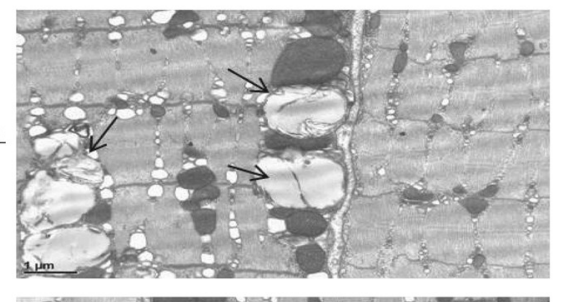

EDL

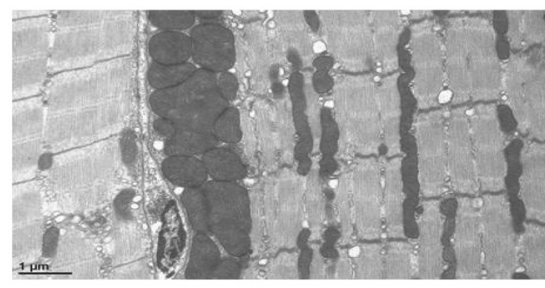

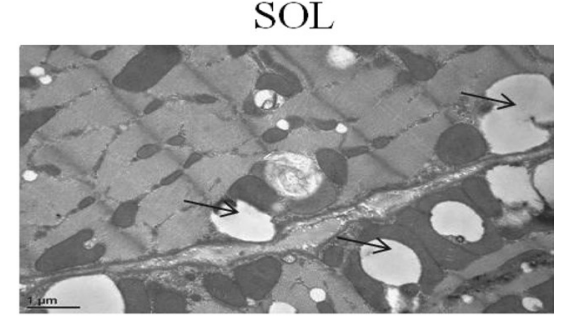



SOL
Fig. 1. Assessment of lipid accumulation in extensor digitorum (EDL) and soleus (SOL) muscles of adipose triglyceride lipase (ATGL) $^{-1-}$ and wild-type (WT) mice. A: representative electron microscopy images of EDL and SOL muscle of $\mathrm{ATGL}^{-1-}$ and WT mice. Note the higher amount of lipid droplets (LD; arrows) in muscles of $\mathrm{ATGL}^{-1-}$ mice and its different distribution among neighboring fibers. $B$ : LD frequency density and $\mathrm{LD}$ content in EDL and SOL muscles of $\mathrm{ATGL}^{-1-}$ and WT mice $(n=2$ for both groups). Values presented are means $\pm \mathrm{SE}$; statistical differences indicated with Student's $t$-test for $P<0.05$. **Significantly different from WT, $P<0.01$.
B
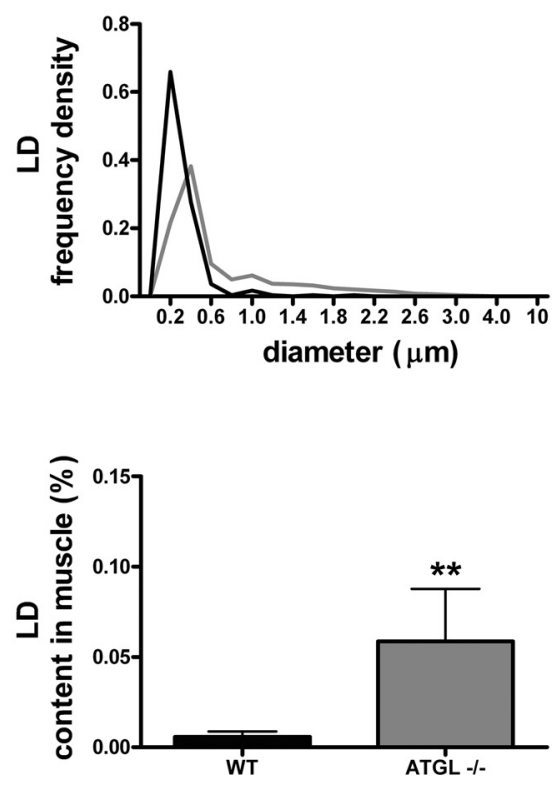
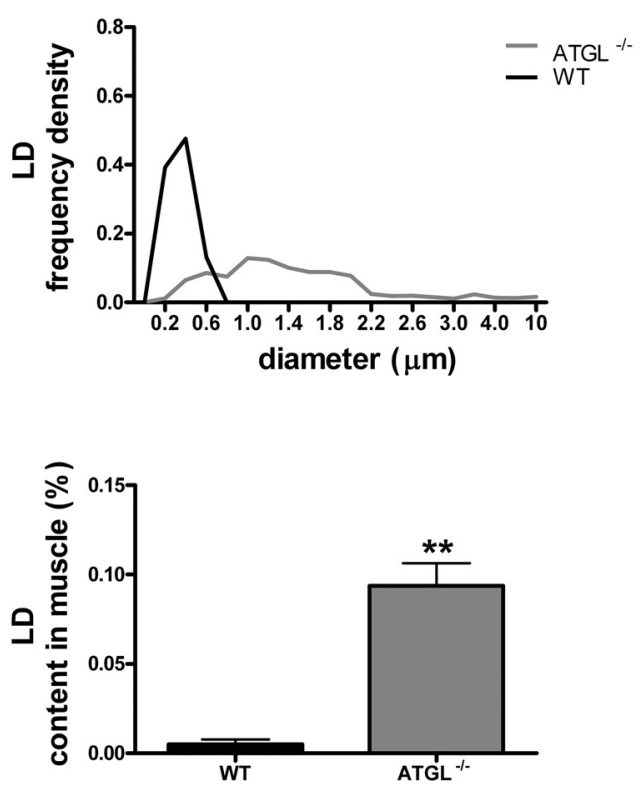

Energy state of the resting skeletal muscle. The ${ }^{31} \mathrm{P}-\mathrm{MR}$ spectra acquired in the resting muscle of WT mice showed resonances assigned to $\mathrm{P}_{\mathrm{i}}, \mathrm{PCr}$, and ATP (Fig. 4). Resting muscles of ATGL ${ }^{-1-}$ and WT mice had similar tissue concentrations of $\mathrm{PCr}$ and $\mathrm{P}_{\mathrm{i}}$, comparable ratios of $\mathrm{PCr} / \mathrm{P}_{\mathrm{i}}$ and $\mathrm{PCr} /$ ATP, and cellular $\mathrm{pH}$ (see Table 2).

In line with the in vivo ${ }^{31} \mathrm{P}$-MRS data, the biochemical determinations of muscle high-energy metabolites showed no significant differences between the groups. The average ATP concentration in freeze-clamped muscles was $28.7 \pm 5.0$ $\mu \mathrm{mol} / \mathrm{g}$ dry $\mathrm{wt}$ for ATGL ${ }^{-1-}$ mice and $33.7 \pm 2.4 \mu \mathrm{mol} / \mathrm{g}$ dry wt for WT mice $(P=0.17)$. PCr concentration was $66.2 \pm$ $10.7 \mu \mathrm{mol} / \mathrm{g}$ dry wt for $\mathrm{ATGL}^{-1-}$ mice and $75.8 \pm 17.6$ $\mu \mathrm{mol} / \mathrm{g}$ dry wt for WT mice $(P=0.40)$.

Muscle performance of $A T G L^{-\prime-}$ and WT mice upon electrostimulation. Mitochondrial oxidative capacity and muscular performance of $\mathrm{ATGL}^{-\prime-}$ mice were evaluated in a combined electrostimulation protocol based on in vivo muscle electrostimulation with gated dynamic ${ }^{31} \mathrm{P}-\mathrm{MRS}$ (24).
Electrostimulation through the sciatic nerve at a frequency of $150 \mathrm{~Hz}$ for $250 \mathrm{~ms}$ resulted in fully fused isometric tetanic contractions of the calf muscle complex in both genotypes, $\mathrm{ATGL}^{-1-}$ and WT mice (see Fig. 5A). The stimulation current applied to achieve maximal force in $\mathrm{ATGL}^{-1-}$ muscles was $1.72 \pm 0.03 \mathrm{~mA}$, significantly lower than the $2.00 \pm 0.06 \mathrm{~mA}$ applied to the WT muscles $(P<0.001)$. This optimal current was then used to stimulate the calf muscle complex to contract every $3 \mathrm{~s}$ over $1 \mathrm{~min}(0.33 \mathrm{~Hz})$. The force produced in the first twitch of the electrostimulation train was substantially lower in $\mathrm{ATGL}^{-1-}$ mice than in the WT mice $(0.016 \pm 0.001$ vs. $0.030 \pm 0.005 \mathrm{~N} / \mathrm{mm}^{-2}, P<0.0001$; Fig. $5 B$ ). Over the 20 isometric contractions, the force produced by the $\mathrm{ATGL}^{-1-}$ mice was persistently lower than that of the WT mice (Fig. 5C). However, the $\mathrm{ATGL}^{-1-}$ mice had a force decay of $29 \pm$ $1 \%$ between the first and the last contraction of the stimulation train, similar to the decay of $27 \pm 2 \%$ for the WT mice. To test whether differences in force production were due to the different electrostimulation currents applied, $\mathrm{ATGL}^{-1-}$ and WT 


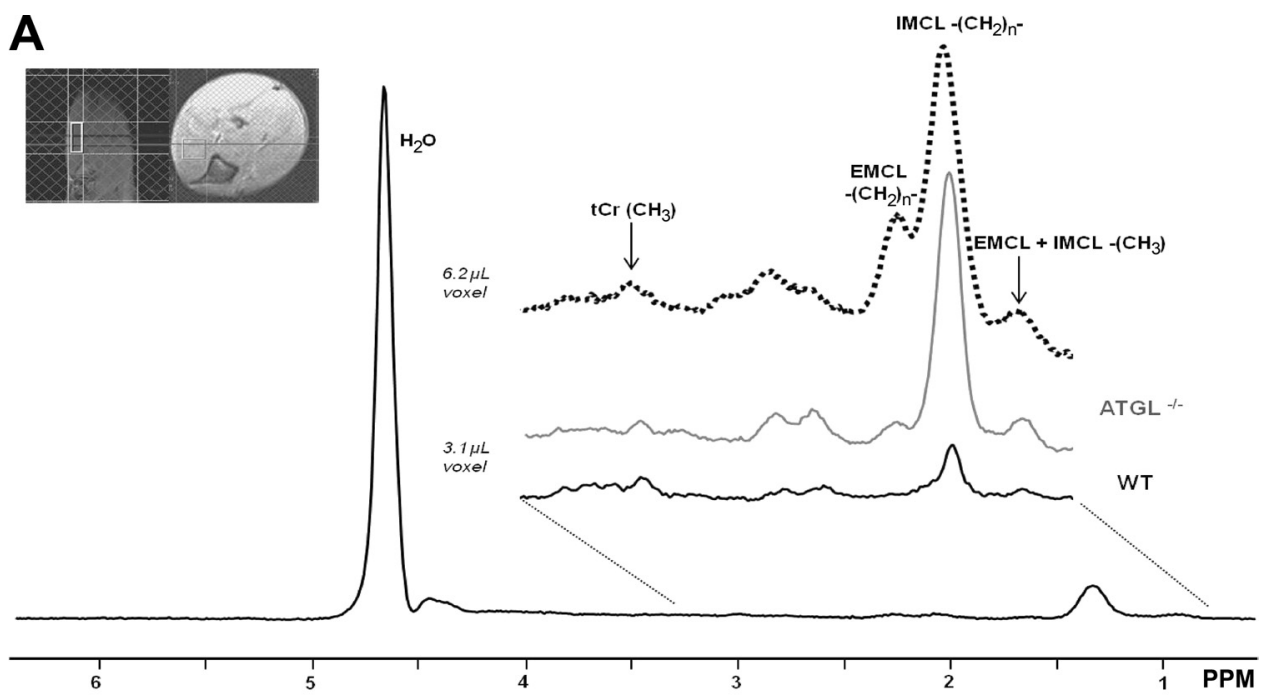

B

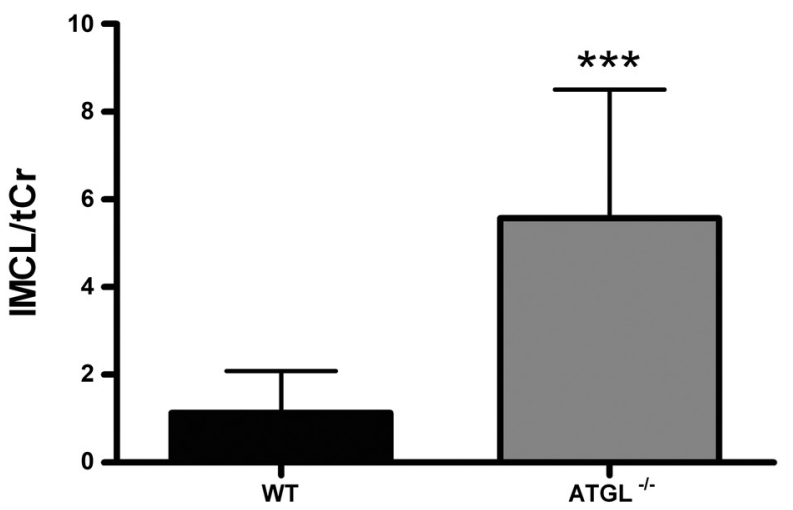

Fig. 2. Intramyocellular lipid (IMCL) content in tibialis anterior (TA) of $\mathrm{ATGL}^{-1-}$ and WT mice. $A$ : representative single-voxel $(3.1 \mu \mathrm{l}){ }^{1} \mathrm{H}$ magnetic resonance (MR) spectrum measured in TA of $\mathrm{ATGL}^{-1-}$ and WT mice. Note that in ${ }^{1} \mathrm{H}-\mathrm{MR}$ spectrum acquired with a 6.2- $\mu$ l voxel, the presence of both extramyocellular lipid (EMCL) and IMCL methylene peaks. $B$ : spectral quantification of IMCL in TA of $n=9$ WT (black bar) and $n=7 \mathrm{ATGL}^{-1-}$ (gray bar) mice. Values are presented as means $\pm \mathrm{SD}$; statistical differences indicated with Student's $t$-test for $P<$ 0.05. ***Significant difference, $P=0.0007$ vs. WT. tCr, total creatine. mice $(n=5)$ were subjected to the same optimal stimulation current of $1.92 \mathrm{~mA}$. Also under these conditions, ATGL ${ }^{-1-}$ mice produced lower force than the WT mice (Fig. 5D).

The muscular relaxation time was determined by the HRT in each tetanic contraction as the time that the force falls from one-half to one-quarter of the maximal value. The HRT of the WT muscles describes a sigmoidal curve and achieved a steady state of relaxation only at the final stage of the stimulation train, around the 17th contraction (see Fig. 5E). The HRT of $\mathrm{ATGL}^{-1-}$ muscles describes an exponential curve, and during the first 10 contractions these animals required more time to relax than the WT muscles $(P<0.01)$. Muscles from the knockout model achieved a stationary phase of relaxation after the 12th contraction. In general, the percentage change of HRT between the first and the last contraction of the cycle was higher in WT mice $(102 \pm 1$ to $125 \pm 3 \%)$ than in $\mathrm{ATGL}^{-1-}$ mice (102 \pm 1 to $113 \pm 2 \%, P<0.01)$, which suggests that $\mathrm{ATGL}^{-\prime-}$ mice present muscular fatigue even at the onset of the electrostimulation protocol.

Although differences in muscular force production and HRT between ATGL ${ }^{-1-}$ and WT mice could theoretically be attributed to muscle mass composition, the levels of $\mathrm{tCr}$ and muscle CSA discarded this possibility. The resting $\mathrm{ATGL}^{-1-}$ and WT muscles had similar $\mathrm{tCr}$ contents, as determined biochemically, with $49.2 \pm 3.5$ vs. $52.4 \pm 17.0 \mu \mathrm{mol} / \mathrm{g}$ dry wt, respectively. Similarly, the muscle CSA determined for the slices with the
A

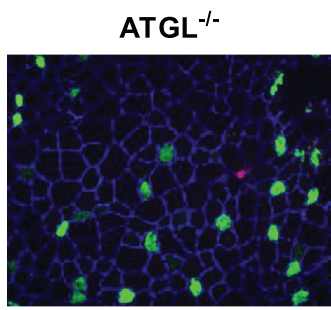

B

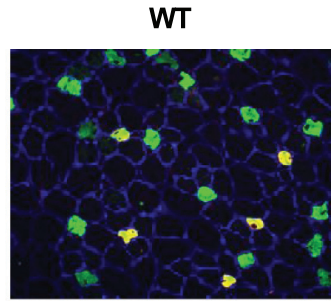

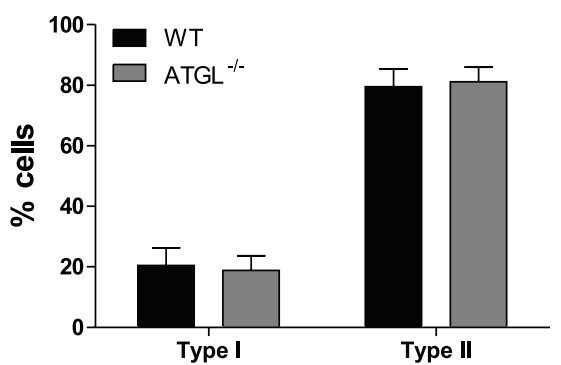

Fig. 3. Fiber typing of TA muscle in $\mathrm{ATGL}^{-1-}$ and WT mice. A: TA crosssectional area of ATGL ${ }^{-1-}$ and WT stained for myosin heavy chain I. Type I fibers (green), type II fibers (not colored), and laminin (blue). $B$ : quantification of type I and type II fibers in TA given in \%cells ( $n=7$ for both groups). Values presented are means \pm SD. 


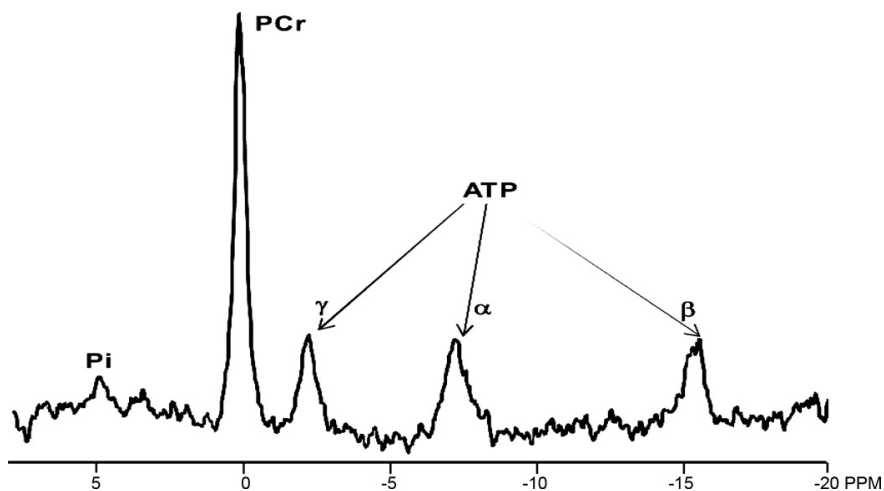

Fig. 4. ${ }^{31} \mathrm{P}-\mathrm{MR}$ spectroscopy of resting skeletal muscle. ${ }^{31} \mathrm{P}-\mathrm{MR}$ spectrum measured in the resting hindlimb of a WT mouse, with 64 averages, repetition time of $10 \mathrm{~s}$, and exponential filter applied. $\mathrm{P}_{\mathrm{i}}$, inorganic phosphate; $\mathrm{PCr}$, phosphocreatine; ATP, adenosine triphosphate $(\gamma, \alpha, \beta)$.

same tibial bone area was $34.8 \pm 1.9 \mathrm{~mm}^{2}$ for $\mathrm{ATGL}^{-1-}$ and $37.7 \pm 5.3 \mathrm{~mm}^{2}$ for WT mice $(P=0.16)$.

Contraction-induced metabolic cost. To meet the energy requirements of a working muscle, creatine kinase operates in the first phase of exercise hydrolyzing $\mathrm{PCr}$ to $\mathrm{Cr}$ and rephosphorylating ADP to ATP. The electrostimulation of the calf muscle complex depleted the PCr pool by $46 \pm 14$ and $41 \pm$ $18 \%$ for $\mathrm{ATGL}^{-1-}$ and WT mice, respectively. For both genotypes, the experienced $\mathrm{PCr}$ depletion during each time point of contraction was correlated with decreased force production. In the $\mathrm{ATGL}^{-1-}$ and in the WT mice, these two parameters correlated positively, suggesting that lower $\mathrm{PCr}$ matched a lower force production (Pearson correlation of 0.76 and $P=0.04$ vs. 0.81 and $P=0.02$, respectively, for $\mathrm{ATGL}^{-1-}$ and WT mice).

Upon PCr depletion, muscle glycogen becomes an important source of energy. In this study, we could not measure contraction-induced glycogen depletion directly. Instead, calf muscles from the contracted and contralateral resting hindlimb were analyzed afterward to compare glycogen content. In the contralateral resting hindlimb, glycogen levels were different between the genotypes (Fig. 6). The ATGL ${ }^{-1-}$ mice had $\sim 30 \%$ less glycogen content than their counterparts $(15.8 \pm 5.3$ vs. $22.2 \pm 6.9 \mu \mathrm{mol}$ glucosyl units/g wet wt, $P<0.05$ ). Independently of the genotype, the glycogen level in the electrostimulated muscles decreased $\sim 50 \%$ compared with contralateral nonstimulated muscles. Similarly to the correlation observed between PCr levels and force production during the electrostimulation, the glycogen consumption inferred from the glycogen variation from nonstimulated to stimulated muscles was positively correlated with the change in force (Pearson correlation of 0.78 and $P=0.04$ vs. 0.83 and $P=0.01$ for $\mathrm{ATGL}^{-1-}$ and WT mice, respectively).

After the muscle electrostimulation protocol, WT $(n=5-8)$ and ATGL $^{-1-}(n=7)$ mice had similar plasma lactate levels (3.7 \pm 1.0 vs. $4.2 \pm 1.2 \mathrm{mM}$, respectively), and plasma glucose was mildly reduced in ATGL ${ }^{-1-}$ mice $(5.8 \pm 2.7 \mathrm{mM}$ compared with WT mice, $8.6 \pm 2.3 \mathrm{mM}, P=0.09)$. The lipid profile of ATGL ${ }^{-1-}$ mice showed a reduction in FFA $(0.42 \pm$ $0.13 \mathrm{mM})$ compared with WT mice $(0.73 \pm 0.30 \mathrm{mM}, P=$ $0.03)$, whereas TG levels were similar between the genotypes $(0.98 \pm 0.12$ vs. $1.24 \pm 0.52 \mathrm{mM}, P=0.12)$.
In vivo muscular mitochondrial oxidative capacity. Gated ${ }^{31} \mathrm{P}-\mathrm{MRS}$ was used to determine in vivo muscular mitochondrial oxidative capacity of $\mathrm{ATGL}^{-1-}$ mice. Figure $7 \mathrm{~A}$ shows a sequence of ${ }^{31} \mathrm{P}-\mathrm{MRS}$ spectra acquired before, during, and after the electrostimulation of the calf muscle complex in one $\mathrm{ATGL}^{-/-}$mouse. Upon stimulation, $\mathrm{PCr}$ is dephosphorylated to $\mathrm{P}_{\mathrm{i}}$ and free $\mathrm{Cr}$ (not visible in ${ }^{31} \mathrm{P}$ spectra), and when stimulation ceases, $\mathrm{PCr}$ is resynthesized to basal levels reflecting mitochondrial oxidative phosphorylation (Fig. 7B). Thus the resynthesis of $\mathrm{PCr}$ is an in vivo measurement for mitochondrial oxidative capacity. Electrostimulation of calf muscle complex induced a PCr depletion of $\sim 43 \%$ and an approximately fivefold increase in $\mathrm{P}_{\mathrm{i}}$ levels in both $\mathrm{ATGL}^{-1-}$ and WT mice (Table 2). Without significant changes in ATP amplitude during the muscle stimulation, the $\mathrm{PCr} / \mathrm{ATP}$ ratio decreased similarly to $\mathrm{PCr}$ concentration, i.e., $\sim 42 \%$ for both groups. In addition, the intracellular $\mathrm{pH}$ of the electrostimulated muscles from $\mathrm{ATGL}^{-1-}$ and WT mice experienced similar reductions.

After the contraction block, muscle $\mathrm{PCr}$ pool was resynthesized to its initial levels. The fitting of the PCr recovery curves was made with a monoexponential function (Fig. 7B) and retrieved the recovery time values expressed graphically in Fig. $7 C$. The mean value of $\tau \mathrm{PCr}$ was $54.1 \pm 6.1 \mathrm{~s}$ for the $\mathrm{ATGL}^{-1-}$ mice and $58.1 \pm 5.8 \mathrm{~s}$ for the WT mice. From these $\tau \mathrm{PCr}$ values, we conclude that, under the experimental conditions applied, $\mathrm{ATGL}^{-1-}$ and WT mice have comparable mitochondrial oxidative capacities.

\section{DISCUSSION}

In this study, we demonstrated that skeletal muscle of $\mathrm{ATGL}^{-1-}$ mice accumulates large amounts of IMCL and shows decreased force production and muscle relaxation; however, no apparent decrease of mitochondrial oxidative capacity was detected.

Physiology of the model. Whole body deletion of ATGL hampers TG lipolysis, resulting in decreased FFA levels and in neutral lipid accumulation in various tissues. This is reflected in the body weight of $\mathrm{ATGL}^{-1-}$ mice and is due exclusively to an increase in fat mass $(18,30)$. Glucose disposal in $\mathrm{ATGL}^{-1-}$ mice, as well as insulin sensitivity, is improved, and after prolonged fasting, plasma glucose levels decrease substantially $(16,19,30)$. At rest, $\mathrm{ATGL}^{-1-}$ mice have reduced glycogen stores $(\sim 30 \%)$ in skeletal muscle, which altogether points toward a reliance on carbohydrates as energy fuel when FFA are not available.

Table 2. Metabolite concentrations and $\mathrm{pH}$ calculated from ${ }^{31} \mathrm{P}$ magnetic resonance spectra acquired at rest and after muscle stimulation of ATGL ${ }^{-1-}(n=9)$ and WT $(n=10)$ mice

\begin{tabular}{|c|c|c|c|c|}
\hline & \multicolumn{2}{|c|}{$\mathrm{ATGL}^{-1-}$} & \multicolumn{2}{|c|}{ WT } \\
\hline & Rest & End stimulation & Rest & End stimulation \\
\hline$[\mathrm{PCr}], \mathrm{mM}$ & $25.6 \pm 7.6$ & $13.2 \pm 6.6$ & $20.1 \pm 6.1$ & $11.8 \pm 4.2$ \\
\hline$\left[\mathrm{P}_{\mathrm{i}}\right], \mathrm{mM}$ & $3.5 \pm 1.7$ & $15.2 \pm 4.6$ & $2.6 \pm 1.9$ & $15.1 \pm 8.2$ \\
\hline$[\mathrm{PCr}] /\left[\mathrm{P}_{\mathrm{i}}\right]$ & $11.4 \pm 10.5$ & $0.9 \pm 0.5$ & $11.1 \pm 9.9$ & $1.1 \pm 0.8$ \\
\hline$[\mathrm{PCr}] /[\gamma \mathrm{ATP}]$ & $3.2 \pm 1.0$ & $2.0 \pm 1.1$ & $2.6 \pm 0.8$ & $1.5 \pm 0.9$ \\
\hline $\mathrm{pH}$ & $7.14 \pm 0.15$ & $6.94 \pm 0.06$ & $7.11 \pm 0.10$ & $7.00 \pm 0.09$ \\
\hline
\end{tabular}

Values are presented as means $\pm \mathrm{SD}$. $\mathrm{PCr}$, phosphocreatine; $\mathrm{P}_{\mathrm{i}}$, inorganic phosphate; ATP, adenosine triphosphate. 

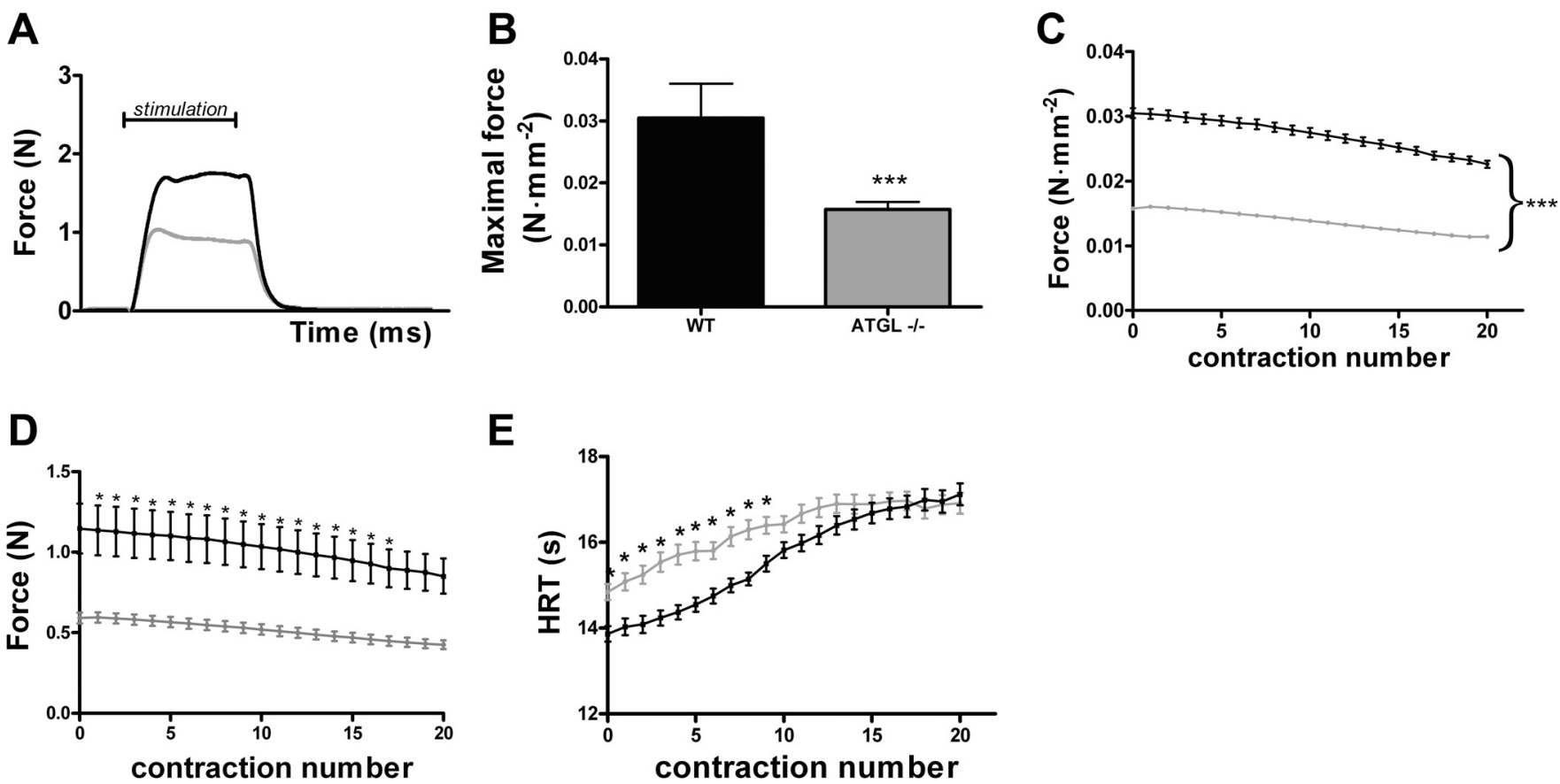

Fig. 5. Muscle contraction profile of ATGL ${ }^{-1-}$ and WT mice. A: example of a fully fused isometric tetanic contraction of calf muscles in ATGL ${ }^{-1-}$ (gray) and WT (black) achieved by electrostimulation for $250 \mathrm{~ms}$ at $150 \mathrm{~Hz}$ of stimulation frequency. $B$ : maximal force produced upon the first muscle twitch of ATGL ${ }^{-1-}$ $\left(n=9\right.$; gray bar) and WT mice $\left(n=10\right.$; black bar). Muscle contraction was achieved by optimal electrostimulation of calf muscles in ATGL ${ }^{-1-}$ mice at $1.72 \pm 0.03 \mathrm{~mA}$ and WT mice at $2.00 \pm 0.06 \mathrm{~mA}$. $C$ : force $\left(\mathrm{N} / \mathrm{mm}^{-2}\right)$ produced in the electrostimulation protocol with 20 isometric tetanic contractions. $D$ : absolute force produced by ATGL ${ }^{-1-}$ and WT mice with a stimulation current of $1.92 \mathrm{~mA}(n=5$ in both groups). E: muscular half relaxation time (HRT) determined in each contraction of ATGL ${ }^{-1-}$ (gray circles) and WT mice $(\bullet)$. Values are presented as means \pm SE; statistical differences were assessed by a Student $t$-test $(B)$ and 2-way ANOVA with Bonferroni posttest $(C-E)$. * and ***Significantly different from WT, $P<0.01$ and $P<0.001$, respectively.

Increased IMCL deposition in skeletal muscle of $A T G L^{-1-}$ mice. IMCL quantification in TA of $\mathrm{ATGL}^{-1-}$ and WT mice by in vivo ${ }^{1} \mathrm{H}$-MRS showed that $\mathrm{ATGL}^{-1-}$ mice have an approximately sixfold increase in IMCL content. The TA muscle was chosen to determine the level of intra- and extramyocellular lipids since its fibers can be oriented parallel to the magnetic field, which essential for a proper discrimination of the ${ }^{1} \mathrm{H}$ resonances of intra- and extramyocellular lipids (3, 4). Our results show that the use of small voxels $(3.1 \mu l)$ in localized ${ }^{1} \mathrm{H}$-MRS enables a selective determination of the IMCL pool in TA of mice, similar to what has been described for rats (32).

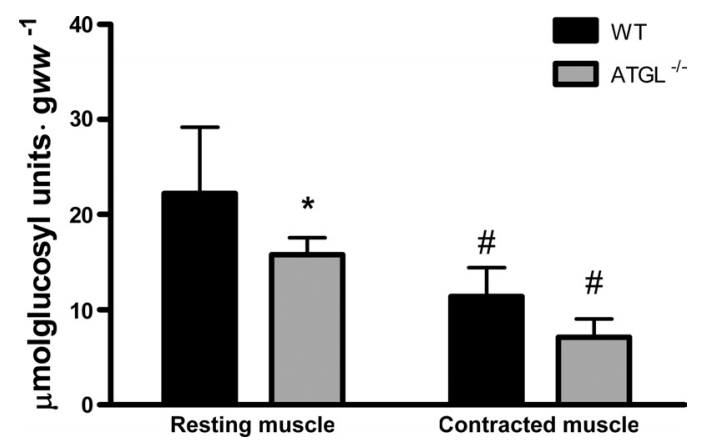

Fig. 6. Contraction-mediated glycogen depletion. Glycogen content on the contracted and contralateral resting calf muscles of $n=9 \mathrm{ATGL}^{-1-}$ (gray bars) and $n=8$ WT (black bars) mice. Values presented are means \pm SD; statistical differences indicated with 2-way ANOVA and Bonferroni posttest. *Different from WT, $P<0.05$; \#different from the respective contralateral resting muscle, $P<0.001$.
Electron microscopy data showed that in $\mathrm{ATGL}^{-1-} \mathrm{SOL}$ muscle, the number and size of the LD is significantly higher than in fast-twitch muscle EDL. Since the TA muscle is composed mainly of fast-twitch type II fibers $(\sim 80 \%)$, as is the EDL, an approximately sixfold increase in IMCL pool is potentially an underestimation for muscles with more oxidative types of fibers. Interestingly, the electron microscopy images also revealed that in $\mathrm{ATGL}^{-1-}$ muscles, neighboring fibers are affected differently by lipid accumulation. This might be related to fiber phenotype, because greater lipid accumulation in $\mathrm{ATGL}^{-1-}$ mice occurs in oxidative rather than in glycolytic fibers (47). Whether this fact is related to ATGL expression in specific muscle fibers, as it happens in human skeletal muscle (21), remains unknown.

Regarding the possible "lipotoxic" interaction between IMCL and mitochondrial function in skeletal muscle, the nature of this lipid accumulation is somewhat of importance. It was shown that $\mathrm{ATGL}^{-1-}$ skeletal muscles accumulate mainly IMCL as neutral TG $(16,19,30)$, whereas ceramide and overall long-chain FA contents were found unaltered or decreased in $\mathrm{ATGL}^{-1-} \mathrm{SOL}$ muscle compared with WT littermates (30).

In vivo mitochondrial oxidative capacity of ATGL ${ }^{-1-}$ mice is similar to WT mice. To evaluate whether skeletal muscle of $\mathrm{ATGL}^{-1-}$ mice had impaired mitochondrial function, we assessed mitochondrial oxidative capacity by ${ }^{31} \mathrm{P}-\mathrm{MRS}$ after maximal muscle contractions in vivo. Upon cessation of an energy-demanding exercise, skeletal muscle mitochondrial oxidative phosphorylation produces ATP, which is used almost exclusively to rephosphorylate $\mathrm{Cr}(1,35)$. Hence, the $\mathrm{PCr}$ resynthesis is an in vivo measurement of mitochondrial oxida- 


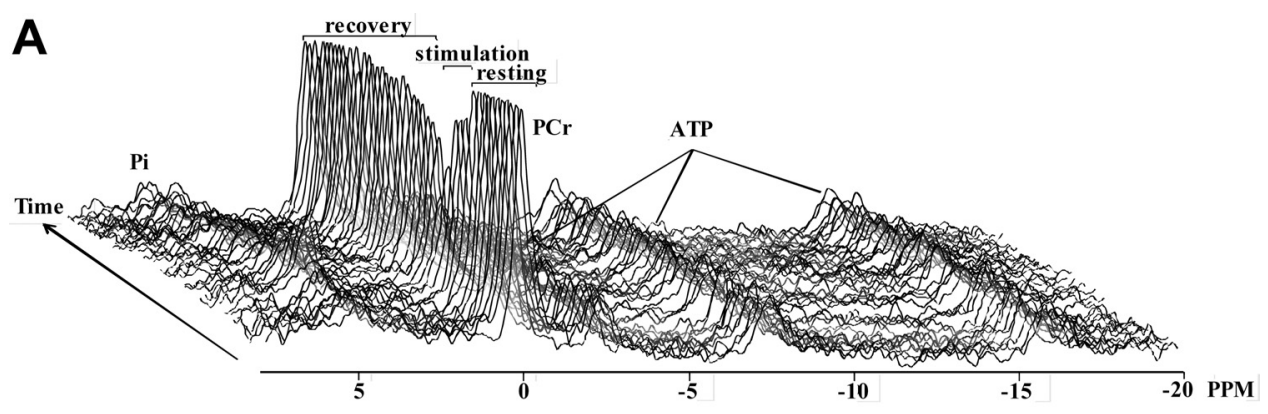

B

Fig. 7. In vivo skeletal muscle mitochondrial oxidative capacity of $\mathrm{ATGL}^{-/-}$and WT mice. A: example of $1{ }^{31} \mathrm{P}-\mathrm{MRS}$ time series measured in hindlimb of $\mathrm{ATGL}^{-/-}$mouse during the resting/stimulation/recovery protocol. Muscle contraction was achieved by electrostimulation of calf muscles at a frequency of $0.33 \mathrm{~Hz}$. Resonances for $\mathrm{P}_{\mathrm{i}}, \mathrm{PCr}$, and ATP are indicated. $B$ : $\mathrm{PCr}$ concentration before, during, and after the $60 \mathrm{~s}$ of electrostimulation (gray bar). Example of the monoexponential fitting of the WT mice PCr recovery curves, with dashed lines representing $95 \%$ confidence interval. $C$ : average $\mathrm{PCr}$ recovery times for $\mathrm{ATGL}^{-1-}(n=9$; gray bar) and WT ( $n=10$; black bar) mice. Values are presented as means $\pm \mathrm{SE}$.

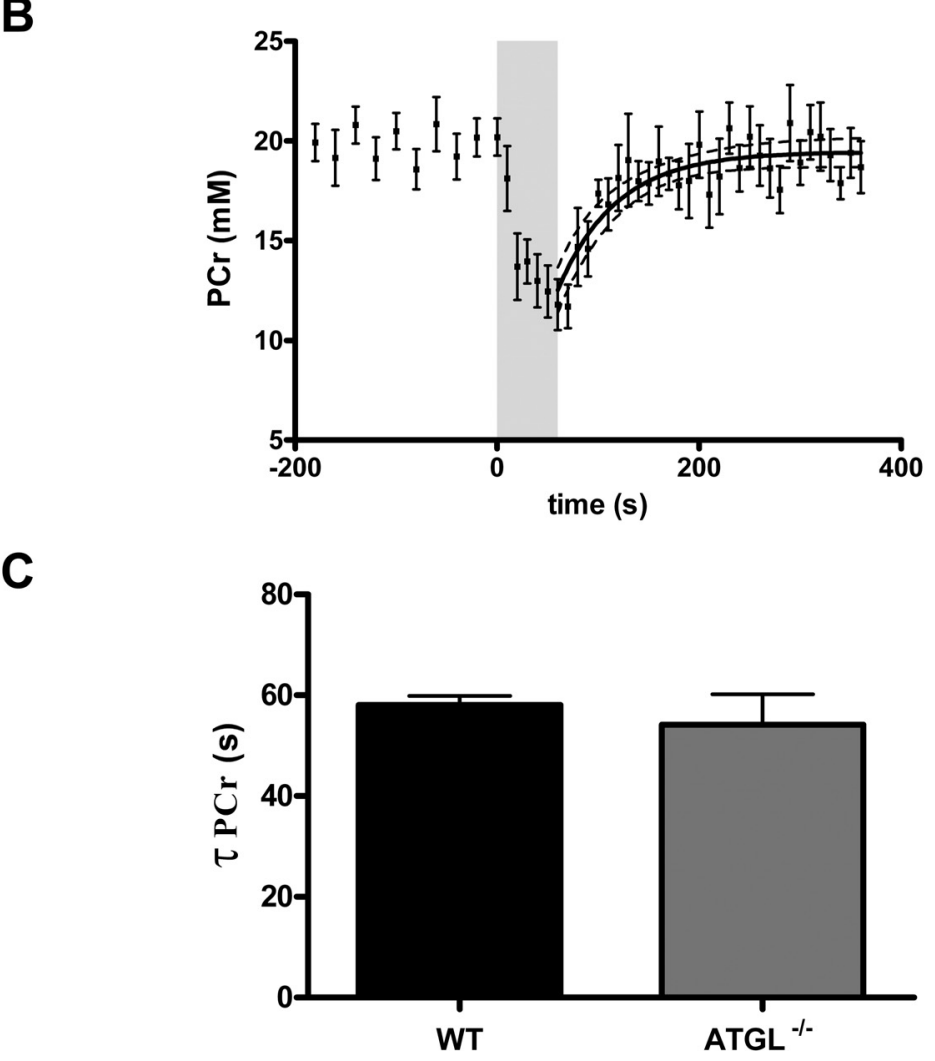

tive capacity and has been widely applied in human $(9,26,55)$ and animal studies $(8,28,52)$ (reviewed in Ref. 27).

Skeletal muscle of ATGL ${ }^{-1-}$ mice presented similar $\tau \mathrm{PCr}$ to the WT mice, which showed that ATGL $^{-1-}$ muscle had comparable mitochondrial oxidative capacity to their counterparts. Electron microscopy images from SOL and EDL muscles did not show differences between $\mathrm{ATGL}^{-/-}$and WT mice regarding mitochondrial localization or morphology. Others also have shown that $\mathrm{ATGL}^{-1-}$ mice on a 4-wk high-fat diet present normal skeletal muscle mitochondrial content. Maximal activities of citrate synthase and $\beta$-hydroxyacyl-CoA dehydrogenase, protein content of respiratory chain complexes, and relative expression of mitochondrial biogenesis genes in the skeletal muscle were also found to be similar between 4-wk high-fat-fed ATGL ${ }^{-1-}$ mice and WT mice (18). When FFA are available they are promptly oxidized either ex vivo in isolated muscle preparations (19) or in vivo when supplied by means of diet (18). These studies indicate that mitochondrial $\beta$-oxidation in skeletal muscle of $\mathrm{ATGL}^{-1-}$ mice is unaffected. In our study, resting or contracting muscles of $\mathrm{ATGL}^{-1-}$ mice had normal ATP concentration, $\mathrm{PCr} / \mathrm{ATP}$ ratio, and $\tau \mathrm{PCr}$ compared with WT mice. Thus, remaining circulating FFA or other substrates (e.g., glucose) seemed to be sufficient to fuel mitochondrial oxidative phosphorylation and sustain the energy requirements of the muscle at rest and during the contractions. It is possible that cardiomyopathy developed by $\mathrm{ATGL}^{-/-}$ mice impairs blood flow and $\mathrm{O}_{2}$ supply to the working muscle and, consequently, the activity of mitochondrial oxidative phosphorylation. A deficiency in $\mathrm{O}_{2}$ supply would result in a decrease in intracellular $\mathrm{pH}$ and an increase in $\tau \mathrm{PCr}$; however, no differences were observed in these parameters as measured in vivo by ${ }^{31} \mathrm{P}-\mathrm{MRS}$. Thus, within the ${ }^{31} \mathrm{P}$-MRS measurement error, the skeletal muscle mitochondrial oxidative capacity of $\mathrm{ATGL}^{-1-}$ mice is unaffected.

Our results indicate that factors such as the inability to generate FFA for muscle oxidation, the possible downregulation of genes involved in ATP synthesis, or the cardiac abnormalities of $\mathrm{ATGL}^{-1-}$ mice do not operate, at least in appre- 
ciable extent, to cause damage in mitochondrial oxidative capacity. Thus, mitochondrial dysfunction in $\mathrm{ATGL}^{-1-}$ mice seems to be located mainly at the level of cardiac tissue with relative sparing of skeletal muscle.

$A T G L^{-1-}$ mice have reduced force production and increased muscle relaxation time. Despite the fact that overall mitochondrial oxidative capacity was not compromised in $\mathrm{ATGL}^{-/-}$ mice, muscle force production and relaxation, determined simultaneously, were impaired significantly.

The calf muscle complex was electrostimulated through the sciatic nerve with optimal current, i.e., the electric current at which the force produced was maximal. In general, in the $\mathrm{ATGL}^{-1-}$ mice this current was significantly lower than in WT mice, and yet the force produced was less than half of the force of the WT mice. This difference in force was not due to the lower optimal stimulation current, because when the same near-optimal current was applied, the force generated by the $\mathrm{ATGL}^{-1-}$ mice remained reduced compared with WT mice. The contraction-induced PCr depletion in WT and $\mathrm{ATGL}^{-1-}$ mice was comparable, which suggests that $\mathrm{ATGL}^{-1-}$ mice had higher energy cost per contraction (lower contractile efficiency). In addition, the skeletal muscle of $\mathrm{ATGL}^{-1-}$ mice required more time to relax than WT mice.

Our results differ from those reported previously for isolated $\mathrm{ATGL}^{-1-}$ muscles, where no differences were observed in force production or in the fatigue rate of EDL and SOL under submaximal contractions (19). The distinct experimental conditions, e.g., stimulation protocol/frequency, as well as the sex of the animals used could account for the converse findings. Huijsman et al. (19) used a stimulation frequency of $60 \mathrm{~Hz}$ in a muscle fatigue protocol for EDL and SOL, whereas we used $150 \mathrm{~Hz}$ for calf muscle complex (i.e., GAST and SOL) contraction. This stimulation frequency produces the highest force in $\operatorname{GAST}$ and $\operatorname{SOL}(10,22,23)$. When the electrostimulation current was lower than the optimal current, e.g., $1.25 \mathrm{~mA}$, no differences in force between WT and $\mathrm{ATGL}^{-\prime-}$ mice could be detected. This indicates that only when $\mathrm{ATGL}^{-1-}$ muscles contract at high force the difference to WT becomes apparent. The presence of defective muscle performance in $\mathrm{ATGL}^{-1-}$ is supported by studies that showed that these mice are exercise intolerant, with reduced maximal running velocity and endurance capacity $(19,47)$.

Contrary to our hypothesis, mitochondrial dysfunction does not explain the poor muscle performance of $\mathrm{ATGL}^{-1-}$ mice, so other potential mechanisms must be responsible for this defect. For instance, a lower optimal stimulation current suggests differences in nerve resistance in $\mathrm{ATGL}^{-1-}$ mice. This could involve the myelin sheaths that insulate the nerve and conduct electric pulses. Since myelin integrity is highly affected in numerous lipid metabolic disorders (reviewed in Ref. 7), reduction of FFA as in $\mathrm{ATGL}^{-1-}$ mice could compromise its function. Another possible explanation is a mechanical contraction defect in the muscle filaments due to excessive IMCL accumulation and extremely large LDs in $\mathrm{ATGL}^{-1-}$ muscles. Furthermore, $\mathrm{Ca}^{2+}$ handling at the sarcoplasmic reticulum (SR) may be involved, for instance, caused by lower levels of glycogen. Reductions in force production, $\mathrm{Ca}^{2+}$ release, and inhibition of contractile protein are closely associated with reduced muscle glycogen $(6,37)$ due to tight association of glycogen and glycolytic enzymes to the SR $(13,31)$. A reduction in glycogen could lead to a local deficiency in ATP regeneration at the $\mathrm{SR}$, compromising the release of $\mathrm{Ca}^{2+}$ (reviewed in Refs. 2, 14, 34, and 56). And finally, a dysfunction in subsarcolemmal mitochondria, as observed in cardiac muscle of ATGL ${ }^{-1-}$ mice (17), would also lead to compromised $\mathrm{SR} \mathrm{Ca}^{2+}$ reuptake, increased muscle relaxation time, and decreased $\mathrm{SR} \mathrm{Ca}^{2+}$ load in successive contractions $(5,45)$. But subsarcolemmal mitochondrial involvement should be limited or compensated by myofibrillar mitochondria, since within the error of the in vivo ${ }^{31} \mathrm{P}-\mathrm{MRS}$ measurement the overall mitochondrial oxidative capacity was normal.

In conclusion, our in vivo data confirm that whole body ATGL deletion leads to a significant IMCL accumulation in muscle. Different muscles are affected differently, suggesting that IMCL deposition is fiber type dependent. Despite this lipid accumulation and the inability to release fatty acids from IMCL, the in vivo skeletal muscle mitochondrial oxidative capacity of ATGL ${ }^{-1-}$ mice, measured here upon electrostimulation using ${ }^{31} \mathrm{P}-\mathrm{MRS}$, was comparable with that of WT mice. Electrostimulated muscles of $\mathrm{ATGL}^{-1-}$ mice exhibited reduced force production and higher relaxation times than the muscles of WT mice. Because impairment of mitochondrial oxidative phosphorylation does not explain the poor $\mathrm{ATGL}^{-1-}$ muscle performance, other mechanisms must be responsible for this defect.

\section{ACKNOWLEDGMENTS}

We acknowledge W. A. Coumans for expert technical assistance and Dr. G. Kemp for useful comments.

\section{GRANTS}

This research was performed within the framework of the Center for Translational Molecular Medicine (www.ctmm.nl), Project PREDICCt (Grant no. 01C-104), and supported by the Dutch Heart Foundation, Dutch Diabetes Research Foundation, and Dutch Kidney Foundation. Additional support was obtained from European Union project FAST (MRTN-CT-2006-035801).

\section{DISCLOSURES}

No conflicts of interest, financial or otherwise, are declared by the authors.

\section{AUTHOR CONTRIBUTIONS}

P.M.N., M.K.C.H., J.F.G., P.S., C.T., and A.H. did the conception and design of the research; P.M.N., T.v.d.W., A.V., and H.A. performed the experiments; P.M.N. and T.v.d.W. analyzed the data; P.M.N., T.v.d.W., M.K.C.H., P.S., and A.H. interpreted the results of the experiments; P.M.N. prepared the figures; P.M.N. drafted the manuscript; P.M.N., T.v.d.W., A.V., M.K.C.H., J.F.G., P.S., C.T., and A.H. edited and revised the manuscript; P.M.N., T.v.d.W., A.V., H.A., M.K.C.H., J.F.G., P.S., C.T., and A.H. approved the final version of the manuscript.

\section{REFERENCES}

1. Arnold DL, Matthews PM, Radda GK. Metabolic recovery after exercise and the assessment of mitochondrial function in vivo in human skeletal muscle by means of 31P NMR. Magn Reson Med 1: 307-315, 1984.

2. Bendahan D, Giannesini B, Cozzone PJ. Functional investigations of exercising muscle: a noninvasive magnetic resonance spectroscopy-magnetic resonance imaging approach. Cell Mol Life Sci 61: 1001-1015, 2004.

3. Boesch C, Machann J, Vermathen P, Schick F. Role of proton MR for the study of muscle lipid metabolism. NMR Biomed 19: 968-988, 2006.

4. Boesch C, Slotboom J, Hoppeler H, Kreis R. In vivo determination of intra-myocellular lipids in human muscle by means of localized 1H-MRspectroscopy. Magn Reson Med 37: 484-493, 1997.

5. Byrd SK. Alterations in the sarcoplasmic reticulum: a possible link to exercise-induced muscle damage. Med Sci Sports Exerc 24: 531-536, 1992. 
6. Chin ER, Allen DG. Effects of reduced muscle glycogen concentration on force, $\mathrm{Ca}^{2+}$ release and contractile protein function in intact mouse skeletal muscle. J Physiol 498: 17-29, 1997.

7. Chrast R, Saher G, Nave KA, Verheijen MH. Lipid metabolism in myelinating glial cells: lessons from human inherited disorders and mouse models. J Lipid Res 52: 419-434, 2011.

8. De Feyter HM, Lenaers E, Houten SM, Schrauwen P, Hesselink MK, Wanders RJ, Nicolay K, Prompers JJ. Increased intramyocellular lipid content but normal skeletal muscle mitochondrial oxidative capacity throughout the pathogenesis of type 2 diabetes. FASEB J 22: 3947-3955, 2008

9. De Feyter HM, van den Broek NM, Praet SF, Nicolay K, van Loon LJ, Prompers JJ. Early or advanced stage type 2 diabetes is not accompanied by in vivo skeletal muscle mitochondrial dysfunction. Eur J Endocrinol 158: 643-653, 2008.

10. de Haan A. The influence of stimulation frequency on force-velocity characteristics of in situ rat medial gastrocnemius muscle. Exp Physiol 83: 77-84, 1998.

11. de Haan A, Jones DA, Sargeant AJ. Changes in velocity of shortening, power output and relaxation rate during fatigue of rat medial gastrocnemius muscle. Pflugers Arch 413: 422-428, 1989.

12. Edwards RH, Hill DK, Jones DA. Metabolic changes associated with the slowing of relaxation in fatigued mouse muscle. $J$ Physiol 251: 287-301, 1975.

13. Entman ML, Keslensky SS, Chu A, Van Winkle WB. The sarcoplasmic reticulum-glycogenolytic complex in mammalian fast twitch skeletal muscle. Proposed in vitro counterpart of the contraction-activated glycogenolytic pool. J Biol Chem 255: 6245-6252, 1980.

14. Favero TG. Sarcoplasmic reticulum $\mathrm{Ca}^{2+}$ release and muscle fatigue. $J$ Appl Physiol 87: 471-483, 1999.

15. Fissoune R, Janier M, Briguet A, Hiba B. In vivo assessment of mouse hindleg intramyocellular lipids by $1 \mathrm{H}-\mathrm{MR}$ spectroscopy. Acad Radiol 16 : 890-896, 2009.

16. Haemmerle G, Lass A, Zimmermann R, Gorkiewicz G, Meyer C, Rozman J, Heldmaier G, Maier R, Theussl C, Eder S, Kratky D, Wagner EF, Klingenspor M, Hoefler G, Zechner R. Defective lipolysis and altered energy metabolism in mice lacking adipose triglyceride lipase. Science 312: 734-737, 2006.

17. Haemmerle G, Moustafa T, Woelkart G, Buttner S, Schmidt A, van de Weijer T, Hesselink M, Jaeger D, Kienesberger PC, Zierler K, Schreiber R, Eichmann T, Kolb D, Kotzbeck P, Schweiger M, Kumari M, Eder S, Schoiswohl G, Wongsiriroj N, Pollak NM, Radner FP, Preiss-Landl K, Kolbe T, Rulicke T, Pieske B, Trauner M, Lass A, Zimmermann R, Hoefler G, Cinti S, Kershaw EE, Schrauwen P, Madeo F, Mayer B, Zechner R. ATGL-mediated fat catabolism regulates cardiac mitochondrial function via PPAR-alpha and PGC-1. Nat Med 17: 1076-1085, 2011.

18. Hoy AJ, Bruce CR, Turpin SM, Morris AJ, Febbraio MA, Watt MJ. Adipose triglyceride lipase-null mice are resistant to high-fat diet-induced insulin resistance despite reduced energy expenditure and ectopic lipid accumulation. Endocrinology 152: 48-58, 2011.

19. Huijsman E, van de Par C, Economou C, van der Poel C, Lynch GS, Schoiswohl G, Haemmerle G, Zechner R, Watt MJ. Adipose triacylglycerol lipase deletion alters whole body energy metabolism and impairs exercise performance in mice. Am J Physiol Endocrinol Metab 297: E505-E513, 2009

20. in 't Zandt HJ, de Groof AJ, Renema WK, Oerlemans FT, Klomp DW, Wieringa B, Heerschap A. Presence of (phospho)creatine in developing and adult skeletal muscle of mice without mitochondrial and cytosolic muscle creatine kinase isoforms. J Physiol 548: 847-858, 2003.

21. Jocken JW, Smit E, Goossens GH, Essers YP, van Baak MA, Mensink M, Saris WH, Blaak EE. Adipose triglyceride lipase (ATGL) expression in human skeletal muscle is type I (oxidative) fiber specific. Histochem Cell Biol 129: 535-538, 2008.

22. Jones DA, Round JM. Skeletal Muscle in Health and Disease: a Textbook of Muscle Physiology. Manchester, UK: Manchester University, 1990

23. Kan HE, Buse-Pot TE, Peco R, Isbrandt D, Heerschap A, de Haan A. Lower force and impaired performance during high-intensity electrical stimulation in skeletal muscle of GAMT-deficient knockout mice. Am J Physiol Cell Physiol 289: C113-C119, 2005.

24. Kan HE, Veltien A, Arnts H, Nabuurs CI, Luijten B, de Haan A, Wieringa B, Heerschap A. Gated dynamic 31P MRS shows reduced contractile phosphocreatine breakdown in mice deficient in cytosolic creatine kinase and adenylate kinase. NMR Biomed 22: 523-531, 2009.

25. Kelley DE, Goodpaster B, Wing RR, Simoneau JA. Skeletal muscle fatty acid metabolism in association with insulin resistance, obesity, and weight loss. Am J Physiol Endocrinol Metab 277: E1130-E1141, 1999.

26. Kemp GJ, Radda GK. Quantitative interpretation of bioenergetic data from $31 \mathrm{P}$ and $1 \mathrm{H}$ magnetic resonance spectroscopic studies of skeletal muscle: an analytical review. Magn Reson Q 10: 43-63, 1994.

27. Kemp GJ, Roberts N, Bimson WE, Bakran A, Harris PL, GillingSmith GL, Brennan J, Rankin A, Frostick SP. Mitochondrial function and oxygen supply in normal and in chronically ischemic muscle: a combined 31P magnetic resonance spectroscopy and near infrared spectroscopy study in vivo. J Vasc Surg 34: 1103-1110, 2001.

28. Kemp GJ, Taylor DJ, Radda GK. Control of phosphocreatine resynthesis during recovery from exercise in human skeletal muscle. NMR Biomed 6: 66-72, 1993.

29. Kershaw EE, Hamm JK, Verhagen LA, Peroni O, Katic M, Flier JS. Adipose triglyceride lipase: function, regulation by insulin, and comparison with adiponutrin. Diabetes 55: 148-157, 2006.

30. Kienesberger PC, Lee D, Pulinilkunnil T, Brenner DS, Cai L, Magnes C, Koefeler HC, Streith IE, Rechberger GN, Haemmerle G, Flier JS, Zechner R, Kim YB, Kershaw EE. Adipose triglyceride lipase deficiency causes tissue-specific changes in insulin signaling. J Biol Chem 284: 30218-30229, 2009.

31. Korge P, Campbell KB. The importance of ATPase microenvironment in muscle fatigue: a hypothesis. Int J Sports Med 16: 172-179, 1995.

32. Kuhlmann J, Neumann-Haefelin C, Belz U, Kalisch J, Juretschke HP, Stein M, Kleinschmidt E, Kramer W, Herling AW. Intramyocellular lipid and insulin resistance: a longitudinal in vivo $1 \mathrm{H}$-spectroscopic study in Zucker diabetic fatty rats. Diabetes 52: 138-144, 2003.

33. Lake AC, Sun Y, Li JL, Kim JE, Johnson JW, Li D, Revett T, Shih HH, Liu W, Paulsen JE, Gimeno RE. Expression, regulation, and triglyceride hydrolase activity of Adiponutrin family members. J Lipid Res 46: 2477-2487, 2005.

34. Lees SJ, Williams JH. Skeletal muscle sarcoplasmic reticulum glycogen status influences $\mathrm{Ca}^{2+}$ uptake supported by endogenously synthesized ATP. Am J Physiol Cell Physiol 286: C97-C104, 2004.

35. Meyer RA. A linear model of muscle respiration explains monoexponential phosphocreatine changes. Am J Physiol Cell Physiol 254: C548-C553, 1988.

36. Naressi A, Couturier C, Devos JM, Janssen M, Mangeat C, de Beer R, Graveron-Demilly D. Java-based graphical user interface for the MRUI quantitation package. MAGMA 12: 141-152, 2001.

37. Nielsen J, Schroder HD, Rix CG, Ortenblad N. Distinct effects of subcellular glycogen localization on tetanic relaxation time and endurance in mechanically skinned rat skeletal muscle fibres. J Physiol 587: 36793690, 2009.

38. Ong KT, Mashek MT, Bu SY, Greenberg AS, Mashek DG. Adipose triglyceride lipase is a major hepatic lipase that regulates triacylglycerol turnover and fatty acid signaling and partitioning. Hepatology 53: 116126, 2011.

39. Parish R, Petersen KF. Mitochondrial dysfunction and type 2 diabetes. Curr Diab Rep 5: 177-183, 2005.

40. Petersen KF, Dufour S, Befroy D, Garcia R, Shulman GI. Impaired mitochondrial activity in the insulin-resistant offspring of patients with type 2 diabetes. $N$ Engl J Med 350: 664-671, 2004.

41. Peyot ML, Guay C, Latour MG, Lamontagne J, Lussier R, Pineda M, Ruderman NB, Haemmerle G, Zechner R, Joly E, Madiraju SR, Poitout V, Prentki M. Adipose triglyceride lipase is implicated in fueland non-fuel-stimulated insulin secretion. J Biol Chem 284: $16848-$ 16859,2009

42. Pinent M, Hackl H, Burkard TR, Prokesch A, Papak C, Scheideler M, Hammerle G, Zechner R, Trajanoski Z, Strauss JG. Differential transcriptional modulation of biological processes in adipocyte triglyceride lipase and hormone-sensitive lipase-deficient mice. Genomics 92: 26-32, 2008

43. Popesco P, Rajtová V, Horák J. A Colour Atlas of the Anatomy of Small Laboratory Animals (1st ed.). London: Elsevier Health Sciences, 2003.

44. Roden M. Muscle triglycerides and mitochondrial function: possible mechanisms for the development of type 2 diabetes. Int J Obes (Lond) 29 , Suppl 2: S111-S115, 2005.

45. Rossi AE, Boncompagni S, Wei L, Protasi F, Dirksen RT. Differential impact of mitochondrial positioning on mitochondrial $\mathrm{Ca}^{2+}$ uptake and 
$\mathrm{Ca}^{2+}$ spark suppression in skeletal muscle. Am J Physiol Cell Physiol 301: C1128-C1139, 2011.

46. Samuel VT, Petersen KF, Shulman GI. Lipid-induced insulin resistance: unravelling the mechanism. Lancet 375: 2267-2277, 2010.

47. Schoiswohl G, Schweiger M, Schreiber R, Gorkiewicz G, Preiss-Landl K, Taschler U, Zierler KA, Radner FP, Eichmann TO, Kienesberger PC, Eder S, Lass A, Haemmerle G, Alsted TJ, Kiens B, Hoefler G, Zechner R, Zimmermann R. Adipose triglyceride lipase plays a key role in the supply of the working muscle with fatty acids. J Lipid Res 51: 490-499, 2010.

48. Schrauwen-Hinderling VB, Roden M, Kooi ME, Hesselink MK, Schrauwen P. Muscular mitochondrial dysfunction and type 2 diabetes mellitus. Curr Opin Clin Nutr Metab Care 10: 698-703, 2007.

49. Shortreed KE, Krause MP, Huang JH, Dhanani D, Moradi J, Ceddia RB, Hawke TJ. Muscle-specific adaptations, impaired oxidative capacity and maintenance of contractile function characterize diet-induced obese mouse skeletal muscle. PLoS One 4: e7293, 2009.

50. Taylor DJ, Bore PJ, Styles P, Gadian DG, Radda GK. Bioenergetics of intact human muscle. A 31P nuclear magnetic resonance study. Mol Biol Med 1: 77-94, 1983

51. Turpin SM, Hoy AJ, Brown RD, Rudaz CG, Honeyman J, Matzaris M, Watt MJ. Adipose triacylglycerol lipase is a major regulator of hepatic lipid metabolism but not insulin sensitivity in mice. Diabetologia 54: 146-156, 2011.
52. van den Broek NM, Ciapaite J, De Feyter HM, Houten SM, Wanders RJ, Jeneson JA, Nicolay K, Prompers JJ. Increased mitochondrial content rescues in vivo muscle oxidative capacity in long-term high-fatdiet-fed rats. FASEB $J$ 24: 1354-1364, 2010.

53. Vanhamme L, van den Boogaart A, Van Huffel S. Improved method for accurate and efficient quantification of MRS data with use of prior knowledge. J Magn Reson 129: 35-43, 1997.

54. Villena JA, Roy S, Sarkadi-Nagy E, Kim KH, Sul HS. Desnutrin, an adipocyte gene encoding a novel patatin domain-containing protein, is induced by fasting and glucocorticoids: ectopic expression of desnutrin increases triglyceride hydrolysis. J Biol Chem 279: 47066-47075, 2004.

55. Walter G, Vandenborne K, Elliott M, Leigh JS. In vivo ATP synthesis rates in single human muscles during high intensity exercise. $J$ Physiol 519: 901-910, 1999.

56. Westerblad H, Allen DG, Bruton JD, Andrade FH, Lannergren J. Mechanisms underlying the reduction of isometric force in skeletal muscle fatigue. Acta Physiol Scand 162: 253-260, 1998.

57. Wynants J, Van Belle H. Single-run high-performance liquid chromatography of nucleotides, nucleosides, and major purine bases and its application to different tissue extracts. Anal Biochem 144: 258-266, 1985.

58. Zimmermann R, Strauss JG, Haemmerle G, Schoiswohl G, BirnerGruenberger R, Riederer M, Lass A, Neuberger G, Eisenhaber F, Hermetter A, Zechner R. Fat mobilization in adipose tissue is promoted by adipose triglyceride lipase. Science 306: 1383-1386, 2004.

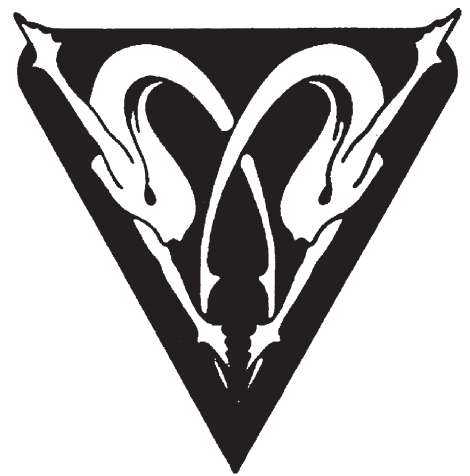

